International Journal of Economics, Business and Accounting Research (IJEBAR)

Peer Reviewed - International Journal

Vol-4, Issue-3, 2020 (IJEBAR)

E-ISSN: 2614-1280 P-ISSN 2622-4771

http://jurnal.stie-aas.ac.id/index.php/IJEBAR

\title{
POSITIVE VALUE OF COVID 19 PANDEMIC FOR MSMEs: A CASE STUDY IN YOGYAKARTA
}

\author{
Sugiyanto ${ }^{1}$, Dewi Suma ${ }^{2}$, Prayekti $^{3}$ \\ ${ }^{1}$ High School Village Development Community “APMD” Yogyakarta Indonesian \\ ${ }^{2}$ Faculty of Economic Universitas Pembinaan Masyarakat Indonesia Medan \\ ${ }^{3}$ Faculty of Economic Universitas Sarjanawiyata Tamansiswa Yogyakarta \\ Email:probosugivanto@Gmail.com
}

\begin{abstract}
The research entitled the positive value of the covid-19 pandemic for MSMEs in Yogyakarta City was motivated by the covid-19 pandemic in Indonesia, starting with the findings of Covid-19 sufferers on March 2, 2020 to April 18, 2020, 6,248 confirmed positive cases of Covid-19 with 631 recovered cases and 535 died cases. As a result of the Covid-19 pandemic, the Government has established various policies such as social distancing, PSBB, learning-working-worshiping at home. The impact of the policy was that various social, tourism and economic activities stagnated. The impact of this stagnation has an impact on MSME actors in general, including MSMEs in Yogyakarta. A qualitative research approach is a case study of MSME actors who are gathered in the home business camp (HBC) and Karang Mitra Usaha (KaMU) in Yogyakarta City. Data were collected through interviews via social media, observation and literature study. Qualitative data analysis used the Creswell 2016 technique. The conclusion of the research was that the reasons behind positive thinking for MSMEs as a result of the Covid-19 epidemic were religious, psychological and educational factors. So that MSME players can take lessons by innovating, evaluating business and developing creativity. Suggestions in research, this research needs to be continued with wider informance and post-Covid-19 MSME actors need to be strengthened through disaster management training for advanced creativity development, psychology, entrepreneurial religiosity and business philosophy.

Keywords: $\quad$ positive value, COVID-19 pandemic, MSMEs Yogyakarta
\end{abstract}

\section{Introduction}

The corona virus pandemic in Indonesia began with the discovery of sufferers of the 2019 coronavirus disease (covid-19) on March 2, 2020. As of April 18, 2020, 6,248 positive cases of Covid-19 were confirmed with 631 cases recovered and 535 died cases. As a result of the Covid -19 pandemic, the Government has established various policies such as social distancing, PSBB, learning-workingworshiping at home. On March 14, 2020, the Indonesian Government declared the corona virus pandemic a national disaster.

Data on Covid-19 victims in the Special Region of Yogyakarta (DIY) 67 positive cases, 26 cases recovered and 7 deaths. On March 15, 2020 the Governor of Yogyakarta, Sri Sultan Hamengkubuwana X, set 5 points in addressing the Covid-19 epidemic, namely: 1) Up-to-date information on the development of corona virus patients in DIY. 2) People (PDP) who are known to be positively infected with the corona virus will be financed by the central government, while the cost of examining people (ODP) who turns out to be negative for the corona virus will be borne by the DIY government. 3) The regional quarantine scheme cannot be implemented because Yogyakarta is still considered not to be an outbreak of the corona virus. 4) The Sultan hopes that secondary schools that will face the National Examination will continue to 
International Journal of Economics, Business and Accounting Research (IJEBAR)

Peer Reviewed - International Journal

Vol-4, IsSue-3, 2020 (IJEBAR)

E-ISSN: 2614-1280 P-ISSN 2622-4771

http://jurnal.stie-aas.ac.id/index.php/IJEBAR

carry out these examinations, and recommend the implementation of online teaching. 5) The people of Yogyakarta are encouraged to anticipate and take precautions, such as maintaining cleanliness and washing hands.

The socio-economic impacts of the Covid-19 epidemic include: 1) triggering the price of medical masks in Indonesia to jump more than six times, with the initial retail price of around IDR 30,000 to IDR 185,000 (some sources say more than IDR 800,000) per box and there is an accumulation of products. 2) Resulting in a downward trend in share prices around the world, weakening the Jakarta Composite Index (IHSG). 3) Stock trading has been suspended due to the Covid-19 pandemic. 4) Cessation of Stock Exchange trading and trading halt. This all resulted in a decrease in the rupiah exchange rate until the rupiah exchange rate weakened to around Rp 15,000, resulting in a decrease in income for all levels of society. On this basis, the Government has responded by compiling a study of the economic impact and decreasing income of the community in each province based on a mild, moderate, and bad scenario. The scenario refers to the economic resilience of each province and the decline in income of economic actors.

Yogyakarta as a city of education and tourism was completely paralyzed because this policy applies to private companies, even some offices are closed or not operational, such as the Indonesian Grab Company from 12 to 17 March 2020 closing its head office and asking its employees to work at home. Given that $90 \%$ of MSME activities in Yogyakarta City serve tourists, students and university students, the income of MSME has also decreased drastically. So that the situation of MSME players with the Covid-19 epidemic is very different from the situation in the global crisis that occurred in 1998. Because when the global crisis occurred, MSMEs did not have a negative impact, they continued to exist with their activities so that it had no effect on income. MSME actors in Yogyakarta City respond to various government policies with evidence of following recommendations and stages of various activities such as data collection of MSMEs affected by COVID-19 victims, exemption from loan installments, discounts on electricity payments and so on. But some MSME players in Yogyakarta City have positive thoughts about the Covid-19 pandemic. On that basis, this study focuses on how MSME actors in the city of Yogyakarta think positively about the Covid-19 pandemic, and how they react to it.

\section{Problem Formulation, Objectives and Research Methods}

The research entitled the positive value of the covid-19 epidemic for case study MSME players in the city of Yogyakarta with the formulation of this research question "what is behind the positive thinking behind the covid-19 epidemic?. So this study aims to determine the real form of positive thoughts behind the Covid-19 epidemic, and what real activities are carried out by MSME actors in the city of Yogyakarta. This research uses a qualitative case study approach. The sample was determined by purposive sampling, the researcher deliberately chose informance with special criteria, namely MSME actors who were actively consulted during the beginning of the Covid-19 epidemic and these actors could provide a lot of information for research purposes (Williamson, 1989 and Gary, 1993). Primary data sources were collected from 25 MSME players through interviews via social media, observations were made on MSME activities independently or integrated with the MSME home business camp (HBC) community and karang mitra usaha (KaMU). Secondary data were collected through literature studies, and data available at the Yogyakarta City Manpower and Transmigration SME Cooperative Office, as well as documentation data in the HBC and KaMU MSME communities.

\section{Literature Review}

The explanation of the literature review will begin with the meaning of covid-19. Because Covid-19 is the subject of emergency conditions for the lives of MSME actors and the lives of other people. The definition of covid-19, is an acronym for corona virus disease 2019. Corona virus is a family of viruses, some of which cause disease in humans, some do not. The new type of corona virus which is currently becoming a pandemic is called severe acute respiratory syndrome-coronavirus, abbreviated as SARS- 
International Journal of Economics, Business and Accounting Research (IJEBAR)

Peer Reviewed - International Journal

Vol-4, IsSue-3, 2020 (IJEBAR)

E-ISSN: 2614-1280 P-ISSN 2622-4771

http://jurnal.stie-aas.ac.id/index.php/IJEBAR

CoV-2. This virus is what causes Covid-19 because of droplets. Droplets are a source of the spread of several diseases, such as tuberculosis and flu, which enter through the mouth and nose. Indonesian suspects are suspected, people suspected of being in the corona pandemic case.

There are two perceptions that arise from social distancing, namely: 1) first is an action taken to prevent sick people from contacting or making close contact with other healthy people. 2) The second meaning relates to the act of staying away from groups of people, mass crowds, or having direct contact with people in large groups. Source of google search engine March 20, 2020. This social restriction policy encourages various initiatives and creativity of MSME actors and maintains their business sustainability..

\subsection{Case Study Research}

This research was conducted briefly because of an emergency situation that moved very quickly, by looking at the varied activities of MSMEs. Data can be obtained quickly because one of the research teams is an expert at the Yogyakarta City Manpower and Transmigration SME Cooperative Office, whose daily activities are to assist MSME players.

The case study approach is a series of scientific activities carried out intensively, in detail and in depth about a program, event and activity; both at the level of individuals, groups of people, and institutions and organizations to obtain in-depth knowledge of the event. In this study, the case chosen by the researcher was the positive impact of covid-19 on MSME actors in the city of Yogyakarta. This case is an actual event because it is ongoing (Smith, 1978) as a "bounded system" and there are other parts that work for the system in an integrative and patterned way. Because it does not stand alone, a case can only be understood when the researcher also understands other cases. When the exploration is carried out indepth, the researcher must go through it with the question of why think positively, what reasons, how are the activities carried out by MSME actors, what is the activity for. This is consistent with the results of the study by Yin (2015) that the words "how" and "why" are used because the two question words are used to gain in-depth knowledge of the symptoms studied. In addition, the form of the question will determine the strategy used to obtain data. The question "how" to ask the process of an event, while the question "why" to find reasons why certain events can occur.

Obtaining reasons about why an action is carried out by the subject must be explored by the researcher from within the subject. Because, it should also be noted that this case study researcher wants to understand the subject's actiosn from the research subject's side, not from the researcher's side. That way, it is hoped that great benefits can be obtained for the development of science, because an event (case) will be raised to the surface until it eventually becomes public knowledge, and researchers believe academically that the positive value of MSME actors in Yogyakarta City towards the Covid-19 pandemic is a weighty case which focuses on contemporary events, which are not a deviation from the norm. So it is necessary to find trends and direction of the development of a case, by following the case study steps formulated by Creswell (2016).

\subsection{Positive Value}

The Latin value, "valere" means, "to be strong," or to be honored. Values are beliefs, choices about "good for humans". Value does not concern the state of this world or what is known at this time, but what the world should or should be (Giddens, 1995). Values can mean religion, politics or ideological principles, beliefs or attitudes. Value in this case is a set of fundamental ethical / moral principles to which the human resources of MSMEs must be committed (Schaefer, 1999).

The role of values as a foundation of basic knowledge that must be possessed by human resources in carrying out their duties and obligations, especially the task of "helping clients" behavior that is driven to help, to be open and honest is the truth. Belief in the truth to do it because the action is right. On the other hand, beliefs about something bad must be prevented so that the individual must avoid it because the act is wrong. Examples of respecting the uniqueness and differences of business actors, maintaining company 
International Journal of Economics, Business and Accounting Research (IJEBAR)

Peer Reviewed - International Journal

Vol-4, IsSue-3, 2020 (IJEBAR)

E-ISSN: 2614-1280 P-ISSN 2622-4771

http://jurnal.stie-aas.ac.id/index.php/IJEBAR

confidentiality, and respecting and protecting fellow business actors in their community are good. Value is a key indication of good bad deeds or right or wrong. Belief in correct values also acts as a guide for all human resources to decide a case when there is an ethical dilemma in business development. While the positive meaning is a way of thinking and attitude, this is what distinguishes someone from having a positive or negative attitude. The meaning of positive thinking is actually very simple. It is true that there are two main ways of thinking, namely, positive thinking or negative thinking. The meaning of positive thinking is a mental attitude that makes us hope for good, even the best and profitable results. Positive characteristics of thinking include always being calm, not easily worried and always trying to be wise in facing life's tests. So MSME players think positively, that the Covid-19 epidemic is a test of life for all business, social, religious, tourism, government and other life, so that it is not only a test for MSME players.

\subsection{MSME}

The definition of Micro, Small and Medium Enterprises (MSME) can refer to Law Number 20 of 2008 concerning Micro, Small and Medium Enterprises (MSME). According to the law, the difference between micro, small and medium enterprises is seen from the value of their assets and the annual turnover. The criteria for dividing asset values and turnover to determine a business, including the type of micro, small, or medium-sized business are presented in table 1.

Table 1. MSME createria based on assets and turnover

\begin{tabular}{|l|l|l|}
\hline Type of business & Asset criteria & Turnover Criteria \\
\hline Micro business & $50.000 .000 ;$ & $300.000 .000 ;$ \\
\hline Small business & $50.000 .000 ;-500.000 .000 ;$ & $300.000 .000 ;-2.5$ billion \\
\hline Medium Enterprises & $500.000 .000 ;-10$ billion & 2.5 milyar-50 billion \\
\hline
\end{tabular}

Source: secondary data 2020

\section{Micro business}

Based on the above criteria, the type of micro business is a business with the criteria of assets not more than IDR 50,000,000 and a turnover of not more than IDR 300,000,000 per year. The definition of a micro business is a productive business owned by an individual and / or an individual business entity that meets the criteria for a Micro Business as regulated in the Law, namely in the form of a maximum asset criteria of IDR 50 million, and a maximum turnover criterion of IDR 300 million.

\section{Small business}

Based on the above criteria, the type of small business is a business with asset criteria of more than IDR $50,000,000$ to IDR 500,000,000, and with a turnover of more than IDR 300,000,000 to a maximum of IDR 2,500,000,000 per year. The definition of small business is an independent productive economic business, carried out by individuals or business entities, and is not a subsidiary or non-branch of a company that is owned, controlled, or is part of, either directly or indirectly, of a medium-sized business or business. large, which meets the criteria for Small Business as referred to in the Law, namely with the criteria for assets between Rp. 50 million to Rp. 500 million, with a turnover criterion between Rp. 300 million - Rp. 2.5 billion.

\section{Medium Enterprises}

Based on the above criteria, the type of medium-sized business is a business with asset criteria of more than IDR 500,000,000 to IDR 10,000,000,000, and with a turnover of more than IDR 2,500,000,000 to a maximum of IDR 50,000,000,000 per year. The definition of a medium-sized business is a productive economic business that stands alone and is carried out by an individual or a business entity that is not a 
International Journal of Economics, Business and Accounting Research (IJEBAR)

Peer Reviewed - International Journal

Vol-4, IsSue-3, 2020 (IJEBAR)

E-ISSN: 2614-1280 P-ISSN 2622-4771

http://jurnal.stie-aas.ac.id/index.php/IJEBAR

subsidiary or branch of a company that is owned, controlled, or part of, either directly or indirectly, of a small or large business, who has the amount of net assets or annual sales proceeds as regulated in the Law, namely the criteria for assets between Rp.500 million-Rp.10 billion, and with the criteria for turnover: > Rp. 2.5 billion - Rp.50 billion rupiah.

\section{Discussion}

The research discussion entitled the positive value of the Covid-19 epidemic for MSMEs in Yogyakarta will begin with the informance profile which has been grouped according to the type of business. Because the Yogyakarta City Manpower and Transmigration SME Cooperative Office fosters four types of business groups, with the Home Business Camp (HBC) forum or community, which is a forum for fostering MSMEs for the younger generation aged 18-30 years and Karang Mitra Usaha (KaMU), which is a forum for developing MSME 30 years old to no age limit. In this study, the two informance commissions are grouped into four types of business, namely: a) informance with the types of culinary and food processing businesses, consisting of: Gethuku, Yossalad, Ayam Geprek, Roselly Pari, Kerren dan Angkringan Jogja b) informance with the types of fashion and accessories businesses, consisting of: Smart Batik, Dea Modist, Lien Collection, Batik Kampung, Javana Collection, Batik "DR",dan Creatif Batik c) informance with the type of handicraft business, consisting of: Dluwang Art, May Craf, Infernocombo, Deby Leather, UNA Craf and Wisudaku and d) informance with the types of service businesses, consisting of: ogja Education Center (YEC), Gosoku, Halo Psikolog, Terapis Massage and Modesta Art.

Tabel 2. Finding Data

\begin{tabular}{|c|c|c|c|c|}
\hline No & Business name & Community & Positive value findings & Data reduction \\
\hline 1 & \multicolumn{2}{|c|}{ Culinary and processed food } & & \\
\hline 1.1 & Gethuku & $\mathrm{HBC}$ & $\begin{array}{l}\text { Face to face marketing is reduced } \\
\text { and moving online, via on line } \\
\text { continues as usual. }\end{array}$ & $\begin{array}{l}\text { Marketing is } \\
\text { amplified online }\end{array}$ \\
\hline 1.2 & YoSSalad & KaMU & $\begin{array}{l}\text { Lots of orders because each buyer is } \\
\text { given a bonus of } 1 \text { mask }\end{array}$ & Bonus strategy \\
\hline 1.3 . & Ayam Geprek & $\mathrm{HBC}$ & $\begin{array}{l}\text { Lots of orders via gofood, because } \\
\text { consumers are afraid to leave, the } \\
\text { positive value is saving jobs. }\end{array}$ & $\begin{array}{l}\text { Demand increases } \\
\text { and job efficiency }\end{array}$ \\
\hline 1.4 & Kerren & $\mathrm{HBC}$ & $\begin{array}{l}\text { Market demand goes up, because } \\
\text { palm sugar is a natural product, and } \\
\text { is useful for increasing endurance. }\end{array}$ & Demand goes up \\
\hline 1.5 & Roselly Pari & $\mathrm{KaMU}$ & $\begin{array}{l}\text { Initially it decreased after returning } \\
\text { to production with natural raw } \\
\text { materials (spices) such as empon } \\
\text { empon, turmeric, ginger etc. it } \\
\text { became stable and could be done } \\
\text { with family, with time efficiency. }\end{array}$ & $\begin{array}{l}\text { Back to natural } \\
\text { products }\end{array}$ \\
\hline 1.6 & $\begin{array}{l}\text { Angkringan } \\
\text { Jogja }\end{array}$ & $\mathrm{HBC}$ & $\begin{array}{l}\text { Income decreased by } 40 \% \text {. } \\
\text { On the positive side, I have to learn } \\
\text { that "force majeure" is applied in } \\
\text { every agreement as a preventive } \\
\text { emergency, etc. }\end{array}$ & $\begin{array}{l}\text { Learn force majeure } \\
\text { for the MoU }\end{array}$ \\
\hline 2 & \multicolumn{2}{|c|}{ Fashion and Accessories } & & \\
\hline 2.1 . & Smart Batik & $\mathrm{HBC}$ & For MSMEs that being able to go & Marketing to online, \\
\hline
\end{tabular}


International Journal of Economics, Business and Accounting Research (IJEBAR)

Peer Reviewed - International Journal

Vol-4, Issue-3, 2020 (IJEBAR)

E-ISSN: 2614-1280 P-ISSN 2622-4771

http://jurnal.stie-aas.ac.id/index.php/IJEBAR

\begin{tabular}{|c|c|c|c|c|}
\hline & & & $\begin{array}{l}\text { online has no impact, improves the } \\
\text { cleanliness and health of the } \\
\text { workplace / production, orders } \\
\text { continue. Mental test for solutions }\end{array}$ & $\begin{array}{l}\text { realizing the } \\
\text { importance of the } \\
\text { health of the } \\
\text { production site }\end{array}$ \\
\hline 2.2 & $\begin{array}{l}\text { Rumah } \\
\text { Jumputan } \\
\text { Srihadi }\end{array}$ & $\mathrm{KaMU}$ & $\begin{array}{l}\text { The positive value of Covid-19: 1) } \\
\text { Having sufficient time to prepare for } \\
\text { the opening of a showroom / gallery } \\
\text { and workshop can be more focused. } \\
\text { 2) Zero defect efforts (reprocessing } \\
\text { failed products into new products and } \\
\text { accelerating the production process } \\
\text { (hand-made tricks replaced with } \\
\text { onthel sewing machines. 4) } \\
\text { developing new products, namely } \\
\text { practicing kraton cooking recipes for } \\
\text { future guests. 5) realizing the } \\
\text { importance of online marketing. }\end{array}$ & $\begin{array}{lr}\text { Process } & \text { failed } \\
\text { products } & \\
\text { Creating } & \text { new } \\
\text { products } & \text { and } \\
\text { developing } & \text { into } \\
\text { culinary } & \\
\text { On line marketing }\end{array}$ \\
\hline 2.3 & Dea Modis & KaMU & $\begin{array}{l}\text { Gathering family, added the initiative } \\
\text { to make patchwork into selling } \\
\text { masks and alms } \\
\text { Stacking products for post-covid-19 } \\
\text { Employees don't want to take } \\
\text { holidays so make stock for post- } \\
\text { Covid-19 }\end{array}$ & $\begin{array}{l}\text { Process patchwork } \\
\text { Continue production } \\
\text { for post-covid-19 }\end{array}$ \\
\hline 2.4 & Batik "DR" & $\mathrm{KaMU}$ & $\begin{array}{l}\text { So understand the meaning of } \\
\text { unexpected savings at a time like } \\
\text { this. } \\
\text { Between actors support each other, } \\
\text { those who are stuck become resellers }\end{array}$ & $\begin{array}{l}\text { Cooperation, } \\
\text { integrated marketing } \\
\text { Savings }\end{array}$ \\
\hline 2.5 & $\begin{array}{l}\text { Javana } \\
\text { Collection }\end{array}$ & $\mathrm{KaMU}$ & $\begin{array}{l}\text { These conditions make SMEs more } \\
\text { creative and resilient in producing } \\
\text { non-medical masks, whether they are } \\
\text { sold or distributed to those in need. }\end{array}$ & $\begin{array}{l}\text { Creative demands } \\
\text { and have to share }\end{array}$ \\
\hline 2.6 . & Lien Collection & KaMU & $\begin{array}{l}\text { More creative, new ideas emerge. } \\
\text { Producing a drink } \\
\text { Tenjaku Serayu } \\
\text { Time management is more efficient } \\
\text { because of flooded orders. }\end{array}$ & $\begin{array}{l}\text { Creative innovation } \\
\text { Turning the brain to } \\
\text { change products from } \\
\text { shibori cloth to } \\
\text { beverage products }\end{array}$ \\
\hline 2.7 & Batik Kampung & $\mathrm{KaMU}$ & $\begin{array}{l}\text { Reading opportunities to replace new } \\
\text { products according to community } \\
\text { needs so that lots of orders. }\end{array}$ & $\begin{array}{l}\text { Change mask } \\
\text { products }\end{array}$ \\
\hline 2.8 & Creative Batik & $\mathrm{HBC}$ & $\begin{array}{l}\text { For batik products that are made to } \\
\text { continue to exist, to strengthen online } \\
\text { marketing, contact old customers to } \\
\text { provide information on various new } \\
\text { products at discounted prices. } \\
\text { Making new products for masks and } \\
\text { PPE clothes. }\end{array}$ & \begin{tabular}{lr}
\multicolumn{2}{l}{ Online marketing } \\
Old & customers \\
prioritize & new \\
products & \\
Think & positive, \\
creatively & manage \\
finances &
\end{tabular} \\
\hline
\end{tabular}


International Journal of Economics, Business and Accounting Research (IJEBAR)

Peer Reviewed - International Journal

Vol-4, Issue-3, 2020 (IJEBAR)

E-ISSN: 2614-1280 P-ISSN 2622-4771

http://jurnal.stie-aas.ac.id/index.php/IJEBAR

\begin{tabular}{|c|c|c|c|c|}
\hline & & & $\begin{array}{l}\text { Positive values are forced to think } \\
\text { positively, creative hard work, work } \\
\text { smart and collaborate and are good at } \\
\text { managing finances. }\end{array}$ & \\
\hline 3 & \multicolumn{2}{|l|}{ Handycraf } & & \\
\hline 3.1 & Infernocombo & $\mathrm{HBC}$ & $\begin{array}{l}\text { There must be a lot of innovation for } \\
\text { adaptation, due to covid- } 19 \text {. } \\
\text { Lower middle consumers Leaving } \\
\text { third class consumers and chasing } \\
\text { class } 1 \text { and } 2 \text { consumers so that they } \\
\text { continue to exist. }\end{array}$ & $\begin{array}{l}\text { Product innovation, } \\
\text { strengthening the } \\
\text { middle to upper } \\
\text { market }\end{array}$ \\
\hline 3.2 & Dluwang Art & $\mathrm{HBC}$ & $\begin{array}{l}\text { Encourage more creative, } \\
\text { opportunities to develop concepts for } \\
\text { new products. }\end{array}$ & $\begin{array}{l}\text { Creativity creates } \\
\text { new concepts }\end{array}$ \\
\hline 3.3 & Deby Leather & $\mathrm{KaMU}$ & $\begin{array}{l}\text { Face to face marketing stopped, but } \\
\text { became an opportunity to explore } \\
\text { digital marketing sales strategies. }\end{array}$ & Online Marketing \\
\hline 3.4 . & May Craf & $\mathrm{HBC}$ & $\begin{array}{l}\text { Trying to survive, focusing on } \\
\text { patchwork mask products }\end{array}$ & $\begin{array}{l}\text { Change product } \\
\text { strategy }\end{array}$ \\
\hline 3.5 & $\begin{array}{l}\text { Una Craf } \\
\text { Hantaran }\end{array}$ & $\mathrm{KaMU}$ & $\begin{array}{l}\text { Learning opportunities with } \\
\text { internship students via online, more } \\
\text { focused and creative. Explore } \\
\text { opportunities and share. }\end{array}$ & $\begin{array}{l}\text { Online marketing and } \\
\text { sharing }\end{array}$ \\
\hline 3.6 & Wisudaku & $\mathrm{HBC}$ & $\begin{array}{l}\text { Opinions have dropped dramatically, } \\
\text { have to spend savings funds, } \\
\text { Positive value is a lot of time to } \\
\text { create new concepts, post-Covid- } 19 \\
\text { will launch new products with } \\
\text { attention to product health. }\end{array}$ & $\begin{array}{lr}\text { A new } & \text { concept } \\
\text { innovation } & \text { for } \\
\text { launching } & \text { after } \\
\text { covid-19 } & \end{array}$ \\
\hline 4 & \multicolumn{2}{|l|}{ Jasa } & & \\
\hline 4.1 . & $\begin{array}{l}\text { Yogja Education } \\
\text { Center (JEC) }\end{array}$ & $\mathrm{HBC}$ & $\begin{array}{l}\text { It is addressed properly by utilizing } \\
\text { the crisis and quarantine conditions: } \\
\text { 1) time for introspection and } \\
\text { evaluation of business processes, } \\
\text { analysis from upstream to } \\
\text { downstream, anything that can be } \\
\text { made effective and efficient. 2) } \\
\text { MSMEs will learn how to manage } \\
\text { financial management, so they know } \\
\text { that there must be cash stored for } \\
\text { emergencies. 3) consumer purchasing } \\
\text { power decreases, so it's time for } \\
\text { quality products. 4) read product } \\
\text { opportunities such as selling masks, } \\
\text { herbal medicine, groceries etc. }\end{array}$ & $\begin{array}{l}\text { Self-introspection, } \\
\text { Creative demands for } \\
\text { the use of } \\
\text { opportunities to } \\
\text { produce quality } \\
\text { goods for the middle } \\
\text { and upper market. It } \\
\text { is important to } \\
\text { schedule an } \\
\text { emergency fund. }\end{array}$ \\
\hline 4.2 . & Halo Psikolog? & $\mathrm{HBC}$ & $\begin{array}{l}\text { Consumers are down, we change the } \\
\text { face to face consulting service model }\end{array}$ & Online service \\
\hline
\end{tabular}


International Journal of Economics, Business and Accounting Research (IJEBAR)

Peer Reviewed - International Journal

Vol-4, IsSue-3, 2020 (IJEBAR)

E-ISSN: 2614-1280 P-ISSN 2622-4771

http://jurnal.stie-aas.ac.id/index.php/IJEBAR

\begin{tabular}{|l|l|l|l|l|}
\hline & & & $\begin{array}{l}\text { with online consulting services, so } \\
\text { that there are still consumers }\end{array}$ & \\
\hline 4.3 & Gosoku & HBC & $\begin{array}{l}\text { Because my business is loundry, } \\
\text { household consumers ar still } \\
\text { running, but office and student } \\
\text { consumers are decreasing. The } \\
\text { positive value of Covid-19 is a a } \\
\text { natural selection event, those who are } \\
\text { not mentally strong are sure to go out } \\
\text { of business, who are mentally strong, } \\
\text { insyalah it will continue. }\end{array}$ & $\begin{array}{l}\text { Must be mentally } \\
\text { strong }\end{array}$ \\
\hline 4.4 & Massage Sehat & Kamu & $\begin{array}{l}\text { People are afraid of massage, so the } \\
\text { income is zero, so I developed the } \\
\text { production of rubbing oil for my own } \\
\text { massage, which is sold online. }\end{array}$ & $\begin{array}{l}\text { Change the product } \\
\text { associated with the } \\
\text { first product }\end{array}$ \\
\hline 4.5 & Modesta Art & KaMU & $\begin{array}{l}\text { Changing direction to produce masks } \\
\text { from washing the patchwork } \\
\text { warehouse so that production } \\
\text { without raw material capital so that } \\
\text { they can exist until now }\end{array}$ & $\begin{array}{l}\text { Change direction to } \\
\text { mask products }\end{array}$ \\
\hline
\end{tabular}

Source: primary data processed in 2020

From table number 2 above, it can be concluded that there are three positive values due to the Covid19 pandemic. The three positive values are: 1) giving birth to or generating new innovations, 2) creative thinking and 3) self-reflection. So that MSME players are able to think positively, move creatively and innovate. This situation is characterized by changing products, taking advantage of conditions and strengthening online marketing. All can survive because they think positive, creative hard work, work smart and collaborate and are good at managing finances. So that some MSMEs become flooded with orders or are on the rise, such as culinary and food processing MSMEs, herbal products and medical devices. The three positive values of the Covid-19 epidemic are discussed in depth as follows.

\subsection{Bringing Up New Innovations}

Referring to the opinion of Zaltman, et.al. (1973), innovation is a new idea, which may be a combination of old ideas into a challenging scheme because of the demands of circumstances and there is a unique value and is accepted as something new. So the feature of innovation is a new idea that is accepted, even though it is like imitation elsewhere (Van de Ven, 1986). This definition includes technical innovations such as new technology, new products, new services or administration or new procedures and new organizational forms. Referring to the definition of innovation above, the forms of innovation carried out by Yogyakarta City MSMEs include:

a. New products, carried out by "SME Smart Batik" in designing thematic batik with the theme of Covid19 and MSME "Liem Collection", because the business of shibori fabrics and new ecoprints is quiet so they think of creating products that have to do with endurance so they are not easily attacked covid-19. This MSME creates a new powder drink that can increase body temperature and body immunity against viruses. This drink is named "tejakuserayu", this name is all short of natural ingredients of ginger, ginger, turmeric lemongrass and cinnamon. This product is flooded with orders so that it is overwhelmed, because people have the confidence to be able to prevent the transmission of the corona-19 virus and its natural ingredients are native to Indonesia. 
International Journal of Economics, Business and Accounting Research (IJEBAR)

Peer Reviewed - International Journal

Vol-4, IsSue-3, 2020 (IJEBAR)

E-ISSN: 2614-1280 P-ISSN 2622-4771

http://jurnal.stie-aas.ac.id/index.php/IJEBAR

b. Processing failed products, carried out by MSMEs "Rumah Jumputan Srihadi" according to the business owner stated, that the positive value of Covid-19, there are five things that can be done, including: “... 1) I have enough time to prepare for the opening of the showroom, which I complete with a workshop space for buyers and people who want to take lessons in making meetings or see the manufacturing process. 2) Apart from that, I am trying to zero defect (process failed products) so that they can be sold at a higher value. 3) I innovate trying to speed up the production process from the tricycle process which is done by hand replaced with an onthel sewing machine. 4) developing new products, namely practicing the recipes of the Kraton dishes for future guests, and 5) realizing the importance of online marketing".

Coincidentally, the location of "Rumah Jumputan Srihadi" is in the south of the southern square of the Ngayojokarta palace and before the Covid-19 epidemic had served jumputan courses for tourists and agencies and the community. As long as tourists or consumers learn to make jumputan "Rumah Jumputan Srihadi", they always provide dishes for the Ngayojokarta palace cash menu, so that the tourists feel happy and interested because the dishes are Yogyakarta food cash.

In connection with the covid-19 epidemic, "Rumah Jumputan Srihadi" was able to fix failed products with a re-coloring process and adding natural scribbles (written batik) turned out to be sold at a higher price with the middle class market and above.

Innovation is actually the initial idea of a creative process and ends with implementation that then becomes a routine (Richardson, 1995). So what was done by three MSME players (Smart Batik, Lien collection and Rumah Jumputan Srihadi) supported the results of the study by Richardson (1995). Because until the end of this research they are still routinely producing it, and according to them it will continue to be developed.

The idea of innovation for the three MSME actors above is the development of the concept of innovation put forward by Verspagen (1991) that innovation as a system comes from institutions and organizations, meaning that the three MSME players have their daily activities join in the HBC and KaMU MSME development forum, in this forum there is always learning. which is interactive, where the state (Yogyakarta City Manpower and Transmigration Office of Cooperatives and SMEs) is the controller. On the other hand, the existence and dynamics of the city of Yogyakarta are inseparable from the dynamics of the Ngayokarta Palace, indirectly the existence of the Keraton provides energy for MSME players as social capital capable of encouraging innovation. So the innovation that was created by the MSME Rumah Jumputan Srihadi and Liem Collection is a new idea that is actually an adoption of the traditional values of the Ngayojakarta Palace, because the Keraton is used as an object by MSME actors and in the Palace there are always cultural activities that MSME players can listen to, this situation is in accordance with the results of the study of Rogers (1995) and Davenport and Volpel (2001). As well as supporting the results of the study of Tricahyadinata (2013) and Yu-Lin Wang (2010), that innovation is a key factor in competition, so even though the crisis conditions due to Covid-19, the three MSMEs still exist because they win in innovation.

\subsection{Creativity}

Etymologically, the word creative comes from English to create, which means to create or create. Thus, creative can be interpreted as creating an idea or concept in solving a problem. According to the Big Indonesian Dictionary, the word "creative" means creativity or has the ability to create. According to Haefele, (1962) creativity is an instinct that humans have since birth. However, creativity cannot develop on its own. Creativity arises because there is stimulation from the environment, so that the environment has an effect on fostering creativity, the conditions for the COVID-19 epidemic are interpreted as stimulation by MSME actors in the city of Yogyakarta. Referring to the creative concepts above, the forms of creativity carried out by Yogyakarta MSME include: 
International Journal of Economics, Business and Accounting Research (IJEBAR)

Peer Reviewed - International Journal

Vol-4, IsSue-3, 2020 (IJEBAR)

E-ISSN: 2614-1280 P-ISSN 2622-4771

http://jurnal.stie-aas.ac.id/index.php/IJEBAR

a. Strengthening online marketing, because face to face marketing is avoided by consumers due to social distancing policies, such as those carried out by Gethuku, Kreatif Batik, Deby Leather, Halo Psikolog, Massage Sehat, Una Craf May Craf and Javana Batik.

b. Utilizing patchwork for new products "personal protective equipment" was carried out by May Craf, Javana Batik, Dea Modist, dan Batik Kampung SMEs

c. Utilizing free time to create new products that will be marketed after covid-19, was carried out by Dea Modist, Wisudaku, Infernocombo and Dluwang Art.

d. Creative in pursuing consumers and improving product quality, meaning that MSME players leave the lower middle class market and pursue the upper middle class market with quality products, carried out by Creative Batik and Infernocombo SMEs.

e. Jossalad did creative in attracting consumers on the grounds of giving PPE bonuses, and health education creative was carried out by Health Massage MSME.

f. Creative to improve the quality of the perpetrator and add other products, such as by MSME Rumah Jumputan Srihadi, Yogya Education Center, and Roselly Pari.

The creativity that has been carried out by the MSME actors above supports the concept of creativity of Guilford (1950), that the actions of MSMEs actors optimize all their own personalities against the environment in a unique and distinctive way. So that there are differences between one MSME actor and another. Creativity in the Process dimension starting from the thinking process to generate unique or creative ideas, then manifested in flexibility to realize originality of thought "(Munandar, 1977).

Because the way someone thinks in solving problems always starts from thinking to find ideas. This idea can be a simple idea, but it is effective in solving a large problem, such as the results of the study by Reni Akbar, et al (2001). Because basically every human being has a creative nature. Everything that has been done by MSME actors above supports the results of Sugiyanto and Musoli's study (2017), that through increasing creativity in MSME resources, MSMEs can maintain and develop new ideas in the form of new products, new packaging, new marketing models, and increased partnerships or networks. which ultimately becomes a competitive economic force.

\subsection{Self-reflection:}

Self-reflection is the process of managing emotions and feelings, and evaluating their experiences. Thus, individuals can realize mistakes and will fix them in the future. Reflection method in psychology is a form of psychology that helps individuals to gain insight. In terms of psychological theory, self-reflection is closely related to humanistic methods and cognitive methods.

The humanistic method is a method that emphasizes the individual's struggle to achieve selfactualization and freedom and the understanding of a person as a totality that has developed potential. The principle of recognition of the importance of personal freedom and responsibility in life-long decisionmaking processes as well as the principle of dynamic and active mind mapping. Through the mind, a person expresses his unique abilities as an individual, manifested in the aspects of cognition, willingness and judgment / considerations related to psychological problems in religion, so that MSME actors only hope for the pleasure of Allah SWT. Because the pleasure of Allah SWT is greater, it is a great fortune (At-Taubah: 72).

Cognitive method, a method that emphasizes the way individuals process information, in particular the way they perceive and remember, think and solve related problems. An understanding of the concept of self-reflection of MSME actors can be seen in the attitude of making decisions in various activities, including:

a. Awareness of the importance of spare money and better understand the meaning of savings, as well as unexpected budgets. As did the MSME Creative Batik, Smart Batik, Jogja Angkringan, Wisudaku, Rubu, Dhea Modist, DR Batik and Yogya Education Center actors. 
International Journal of Economics, Business and Accounting Research (IJEBAR)

Peer Reviewed - International Journal

Vol-4, IsSue-3, 2020 (IJEBAR)

E-ISSN: 2614-1280 P-ISSN 2622-4771

http://jurnal.stie-aas.ac.id/index.php/IJEBAR

b. Sharing, diverting new products, making masks and other PPE are not all sold but some are distributed as charity / worship for those in need, opportunities for charity and being grateful for various favors. As what MSME Batik Kampung, Javana Batik, Dea Modist, Una Craf and May Craf have done. This perpetrator produces PPE, part of which is sold and part of it is sold to parties in need. The reflection process of MSME practitioners has believed that in a narrow moment like this, they are still willing to share, meaning that they believe there is still a way out for them because of Allah SWT and there is still a door of luck to continue their next life. This attitude is in accordance with Al quran surah AthThalaq: 2-3, Whoever believes in Allah is niscahya He will provide for him a way out of all the problems he faces, and give him a fortune from the direction he does not expect.

c. Working together, integrated marketing, learning awareness, mutual support between actors, those who are stuck become resellers. This attitude was expressed by the actors of MSME Creative Batik, Rumah Jumputan Srihadi, Angkringan Jogja and Javana Batik.

d. Recognizing the importance of health in the production environment and having to organize the production site with attention to health and comfort aspects, as did the MSME Smart Batik and Wisudaku actors. This is where MSME actors are grateful for the benefits of being healthy amid the ferocity of Covid-19.

e. Evaluating the business from upstream to downstream so that they have to dare to cut what is less important, this reflection was carried out by MSME Yogja Education Center players, even MSME Gosoku realized more deeply that Covid-19 was a natural selection arena. They believe that all this is Allah SWT who regulates and there is a positive wisdom behind the Covid-19 epidemic, as implied in the Alqur'an surah Ath-Thalaq: 4, whoever believes in Allah, surely He will make it easy for him (all) of his affairs.

MSME actors in this study all understand the Covid-19 epidemic as a blessing from Allah SWT, so they are positive thinking, MSME practitioners do not give up, because they believe that despair is against the grace of Allah SWT, as implied in the Qur'an Surah Al-Hijr: 56, no one is discouraged from the grace of his Rabb, except those who are misguided. This means that MSME practitioners believe that they are not a group of people who are deviant but they are a group of believers.

So that the bad conditions they create into good thoughts and turn positive energy into reality. The impact is that MSME practitioners get a sense of optimism in facing a situation that may be unpleasant, but grateful so that it can create happiness, health, and inner and outer calm in the face of Covid-19 and other impacts.

\section{Conclusion}

Based on the qualitative data analysis, this research can be concluded that the background for MSME actors to identify the positive impact of the Covid-19 epidemic is education, religion and psychology. Although the three factors were not discussed in depth, it was evident from the behavior and decision making of MSME practitioners. Positive behavior that believes in the impact of the COVID-19 epidemic of MSME actors is manifested in three things in decision making, as follows:

a. Conducting new innovations, innovations by finding new products such as what MSME Lien Collection did to create a new product "tejakuserayu" powder drink. The second innovation is to process failed products into high selling value and marketing innovations.

b. Creativity, creativity behavior appears to be very strong in strengthening online marketing, producing PPE from waste raw materials, utilizing free time to create and improve products prepared after Covid-19, chasing middle-class consumers upward, and attracting old consumers to be influenced with a unique new product

c. Self-reflection, the COVID-19 pandemic situation turns out to provide valuable lessons for MSME practitioners in evaluating their business and evaluating themselves. So that they realize the importance of spare money and savings in managing a business, aware that business actors have an 
International Journal of Economics, Business and Accounting Research (IJEBAR)

Peer Reviewed - International Journal

Vol-4, Issue-3, 2020 (IJEBAR)

E-ISSN: 2614-1280 P-ISSN 2622-4771

http://jurnal.stie-aas.ac.id/index.php/IJEBAR

obligation to share, are aware that to be successful they must work together to help each other and must pay attention to the health of products including the health of the production environment.

d. A summary of innovation, creativity and self-reflection forms integrated marketing awareness and product transmigration is left to group members who are able to market online or in other ways, who are unable to market enough production alone, the important thing is that there is an agreement for the results of the marketing process.

It turns out that self-reflection can understand their experiences and relate to other experiences and MSME actors can find new concepts, so that they remain sustainable and competitive, the attitudes of these MSME actors support the results of the study of Melanny, et al. (2018) In order to compete and reclaim market share, development is needed. strategy and innovation, this is necessary because a good innovation will get a response from consumers. So innovation and creativity are important to maintain competitive advantage for consumer satisfaction in MSME (Bunga and Hermansyur, 2017). However, other researchers are welcome to dig deeper into the positive impact of Covid-19 from various perspectives.

\section{References}

Barron, F. 1976. The Psychology of Creativity. Dalam T.M New Comb (editor). Direction in Psychology. New York: Hold, Rinehart \& Winston. Berenson.

Bunga, A dan Hermansyur, HM. 2017. Pengaruh Inovasi dan Kreativitas Terhadap Kepuasan Konsumen Pada MSME Di Kota Medan. Sekolah Tinggi Ilmu Ekonomi harapan Medan. Pusat Ilmu Pengetahuan Terbuka. DOI: 10.31219 / osf.io / ahxju

Creswell, J.W. 2016. Educational Research: Planning, counducting, and evaluating quantitative and qualitative research. Upper Saddle River. NJ: Merrill.

Davenport and Volpel. 2001. Intellectual Capital, Core Assets for the 3rd Millenium. Enterprise. International, The Rise of Knowledge Toward Attention.

Giddens, A., (1995). Constitution of Society: The Outline the Theory of Structuration. Cambridge: Polity Press.

Guilford, J. P. 1950. Creativity. American Psychologist, 5(9), 444-454. https:// https://doi.org/10.1037/h0063487.

Haefele, John. W. 1962. “Creativity and Innovation”. New York: Reinhold. Publishing Corporation.

Isenberg, Joan. P and Marry Renck Jalongo. 1993. Creative Expression And Play In The Early Chilhood Curriculum. Toronto: Maxwell Macmillan Canada.

Melanny M, Gogi.K, Rochim. A.S. 2018. Analisis Orentasi Pasar, Inovasi dan Kreativitas Terhadap Kinerja Pemasaran Pada MSME Di Kabupaten Madiun. Jurnal Dinamika Governance, Vol. 8 No. 2. UPN Jawa Timur.

Munandar. 1977. Creativity and Education. Disertasi, Universitas Indonesia. Jakarta: Departemen Pendidikan dan Kebudayaan

Rachmatsari, P. 2017. Kajian Kreativitas Dan Inovasi Pelaku Usaha Kecil Menegah (UKM) Dalam Upaya Meningkatkan Daya Saing UKM: studi kasus pada wanita pengusaha UKM dii bidang kuliner di kota Bandung. Universitas Pasudan, Bandung.

Reni Akbar-Hawadi dkk, 2001. Psikologi Perkembangan Anak Mengenai Sifat, Bakat dan Kemampuan Anak. GRASINDO, Jakarta. 
International Journal of Economics, Business and Accounting Research (IJEBAR)

Peer Reviewed - International Journal

Vol-4, Issue-3, 2020 (IJEBAR)

E-ISSN: 2614-1280 P-ISSN 2622-4771

http://jurnal.stie-aas.ac.id/index.php/IJEBAR

Richardson, B. 1995. How to Administrate the Networked Organizational Tips from the Theory and Practice of Management. The Learning Organization. Bradford: 1995 vol. 2, Iss 1; pg; 15. http//proquest.umi.com.

Rogers, Everett M, 1995, Diffusions of Innovations, Forth Edition. New York: Tree Press.

Schaefer, D.W.F. 1999. Essencial of Contenporary Advertising. New York:MC. Graww Hill.

Sugiyanto dan Musoli. 2017. Pengembangan Kreativitas Sumberdaya Manusia Pelaku Usaha Mikro Kecil Dan Menengah Dinas Koperasi Tenagakerja Dan Transmigrasi. Jurnal Bisnis: Teori dan Implementasi, Vol. 8 No 2. Universitas Muhammadiyah Yogyakarta.

Tricahyadinata, I. 2013. Kapabilitas Inovasi Usaha Kecil dan Menengah di Indonesia. Jurnal Akuntabel. Vol. 10, No.1. Fakultas Ekonomi Univeritas Wulawarman.

Undang-Undang Republik Indonesia Nomor 20 Tahun 2008 tentang Usaha Mikro, Kecil dan Menengah.

Utami Munandar, 2009. Pengembangan Kreativitas Anak Berbakat. Renika Cipta. Bandung.

Van de Ven. A.H. 1986. Central Problems in The management of innovation, Journal of Management Science (1986-1998): Vol32. No 5, May: ABI/INFORM Global pg.590, Posted in USA.

Verspagen, B. (1991). A new Empirical Approach to Catching up or Falling Behind. Structural Change and Economic Dynamics, 2(2): 359-380.

Wallas. 1990. Theory Regarding Creativity. Book Company, USA., http://moethya26.wordpress.com// Inc., New. York. Yaws .

Yu-Lin Wang, Yau-De Wang, Ruey-Yun Horng. 2010. "Learning and innovation in small and medium enterprises", Journal Industrial Management and Data Systems, Vol. 110 Iss: 2, pp.175192.

Yin, R.K. 2015. Case Study Research: Design and Method. California. Thoussand Oaks: sage Publiscation Inc.

Zaltman, J. Duncan, R., and Holbeck, J. 1973. Innovation and Organization, New York: John Willey. 